J. Clin. Chem. Clin. Biochem.

Vol. 26, 1988, pp. 209-211

(C) 1988 Walter de Gruyter \& Co.

Berlin - New York

\title{
Measurement of Total Serum Protein by Near-Infrared Reflectance Spectroscopy
}

\author{
By A.W. van Toorenenbergen, B. G. Blijenberg and B. Leijnse \\ Department of Clinical Chemistry, Erasmus University/University Hospital Rotterdam-Dijkzigt, Rotterdam, \\ The Netherlands
}

(Received September 24, 1987/January 22, 1988)

Summary: This study describes the measurement of total protein in serum by near-infrared reflectance spectroscopy.

With an algorithm, generated by the calibration procedure, the protein content of serum samples was calculated from absorbance data at various wavelengths in the near-infrared.

A good correlation $(r=0.993)$ was found between near-infrared reflectance spectroscopy measurement of serum protein and analysis by the biuret reaction.

\section{Introduction}

The most widely used method for the determination of total protein in human serum is the biuret reaction (1). Other methods are the Kjeldahl method, the Folin phenol method of Lowry, the Coomassie Blue dye binding method and the $280 / 260 \mathrm{~nm}$ ultraviolet absorption method of Warburg \& Christian $(2,3)$. The absorbance of a protein at $280 \mathrm{~nm}$ depends on the presence of tyrosine and tryptophan in the protein. However, nucleic acids also strongly absorb at $280 \mathrm{~nm}$.

By measurement of the absorbance of a sample at both 280 and $260 \mathrm{~nm}$, the interference of nucleic acid can be eliminated by calculation (3). An analogous approach is used in Near-Infrared Reflectance Spectroscopy (NIRS) (4), a technique that is widely used for the analysis of foods and agricultural products $(4,5)$.

Recently, near-infrared reflectance spectroscopy has also been applied in clinical chemistry:

Koumantakis \& Radcliff (6) used it for the measurement of fat in faeces.

With near-infrared reflectance spectroscopy the $a b$ sorbance of a sample is determined at various wave- lengths in the near-infrared part of the spectrum. With an algorithm, generated by the calibration procedure, the concentration of a specific component in a sample can be calculated. In the present study we show that near-infrared spectroscopy can also be used for the measurement of total protein in serum.

\section{Materials and Methods}

Sera were selected from samples that were submitted for routine profile analysis (sodium, potassium, chloride, calcium, magnesium, bilirubin, creatinine, alkaline phosphatase, total protein and urea) on the Technicon SMAC II Autoanalyser (Technicon Instruments, Gorinchem, The Netherlands). In the SMAC II, serum total protein is measured by the biuret reaction. Sera were chosen with total protein levels that were equally distributed over the range $40-80 \mathrm{~g} / \mathrm{l}$. Near-infrared absorbance of sera was determined with a Technicon InfraAlyzer IA-450 (Bran \& Luebbe/Technicon Industrial Systems, Maarssen, The Netherlands). The basic structure of the InfraAlyzer was recently described in detail by Koumantakis \& Radcliff (6). The InfraAlyzer was connected with a Hewlett-Packard 86B computer, equipped with a Hewlett-Packard 9121 disc drive. For analysis of serum samples a specially designed cuvette (low volume cup, developed by Technicon, the Netherlands, see fig. 1) was used. A small amount of serum was placed on the horizontal reflecting surface in the cuvette (see fig. 1). On adjustment of the glass cover, excess liquid was pressed away. The thickness of the liquid layer between reflecting surface and glass cover was about $0.2 \mathrm{~mm}$. Software for calibration and multiple regression analysis were provided by Technicon (7). 


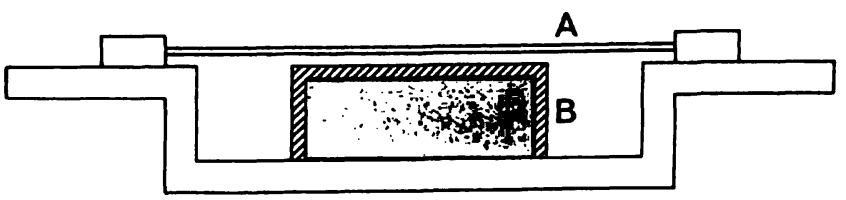

Fig. 1. Scheme of the cuvette used for near-infrared reflectance spectroscopy analysis of liquid samples.

A: circular quartz glass cover.

B: solid cylinder with diffuse reflecting golden surface layer.

\section{Results}

\section{Calibration}

Fourty sera with various concentrations of total protein were used to calibrate the InfraAlyzer. The absorbance of each serum was determined at 19 different wavelengths (between 1440 and $2350 \mathrm{~nm}$ ). The relationship between the absorbance readings and the protein content of the individual samples (as determined by SMAC II) was analysed by multiple linear regression analysis. With a "best set" routine of the multiple linear regression program the regression $\mathrm{F}$ ratio was calculated for all combinations of $2,3, \ldots$, 19 wavelengths. This F-ratio is defined as follows (7):

F-ratio $=\frac{\mathrm{r}^{2}(\mathrm{~N}-\mathrm{k}-1)}{\left(1-\mathrm{r}^{2}\right) \mathrm{k}}$,

where

$\mathrm{r}=$ multiple correlation coefficient

$\mathrm{N}=$ number of samples, used for calibration,

$\mathrm{k}=$ number of wavelengths.

The highest F-ratio was found with a combination of five wavelengths, which are shown in table 1.

The six F-values were loaded into the memory of the InfraAlyzer; The protein content of serum samples could now be calculated by the InfraAlyzer with the following algorithm:

Total protein in serum, gram/1 $\left(\times 10^{-3}\right)=\mathrm{F}_{0}+$ $F_{5} \log \left(1 / R_{5}\right)+F_{13} \log \left(1 / R_{13}\right)+F_{14} \log \left(1 / R_{14}\right)+$ $F_{15} \log \left(1 / R_{15}\right)+F_{20} \log \left(1 / R_{20}\right)$,

where

$F_{0}=$ bias adjustment,

$F_{n}=F$-value of filter $n$,

$R_{n}=$ reflectance measurement with filter $n$.

Tab. 1. Wavelengths for near-infrared reflectance spectroscopy measurement of serum total protein, with the corresponding F-values.

\begin{tabular}{lc}
\hline & F-value \\
\hline Bias $F_{00}$ & 0.114 \\
Filter $F_{05}(2270 \mathrm{~nm})$ & 3.522 \\
Filter $F_{13}(1778 \mathrm{~nm})$ & -6.109 \\
Filter $_{14}(2100 \mathrm{~nm})$ & -0.831 \\
Filter $_{15}(1759 \mathrm{~nm})$ & -7.867 \\
Filter $F_{20}(1680 \mathrm{~nm})$ & 10.784 \\
Regression F-ratio & 514.7 \\
Coefficient of correlation & 0.994 \\
\hline
\end{tabular}

\section{Comparison of NIRS with SMAC-results}

After calibration of the InfraAlyzer with 40 sera, protein in another group of sera was determined by the InfraAlyzer, with the same cuvette that was used for calibration.

Figure 2 shows the correlation between the results, obtained with the InfraAlyzer and the SMAC data. Orthogonal regression analysis of these data gave a correlation coefficient of $0.993(\mathrm{~N}=43$; slope 1.055; intercept -3.445$)$. To evaluate the precision of nearinfrared reflectance spectroscopy analysis, three sera with different concentrations of total protein were analyzed 12 times by the InfraAlyzer. The within-run coefficients of variation were $3.3 \%(\overline{\mathrm{x}}=43.8 \mathrm{~g} / \mathrm{l}, \mathrm{SD}$ $=1.5), 1.9 \%(\overline{\mathrm{x}}=63.8 \mathrm{~g} / \mathrm{l}, \mathrm{SD}=1.2)$ and $1.3 \%$ $(\overline{\mathrm{x}}=99.2 \mathrm{~g} / \mathrm{l}, \mathrm{SD}=1.3)$.

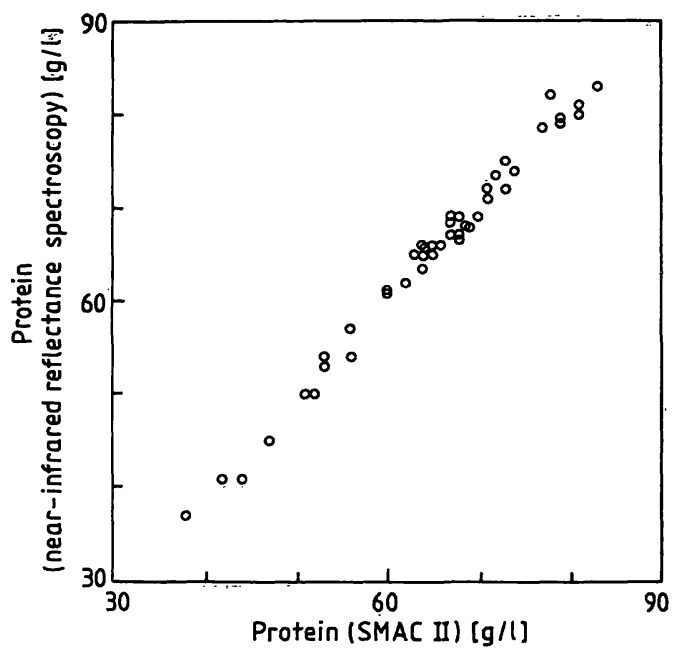

Fig. 2. Total protein in serum, determined by near-infrared reflectance spectroscopy (NIRS) and by the biuret method (SMAC II Autoanalyzer).

Tab. 2. Measurement of total protein in serum with the SMAC II and by near-infrared reflectance spectroscopy (NIRS) in sera with high concentrations of creatinine and/or bilirubin and urea (sera $1=15)$. Serum No. 16 contained $52 \mathrm{~g} / \mathrm{l} \mathrm{IgG.}$

\begin{tabular}{rrrrll}
\hline Serum & $\begin{array}{l}\text { Crea- } \\
\text { tinine } \\
\mu \mathrm{mol} / 1\end{array}$ & $\begin{array}{l}\text { Bili- } \\
\text { rubin } \\
\mu \mathrm{mol} / \mathrm{l}\end{array}$ & $\begin{array}{l}\text { Urea } \\
\text { mmol/1 }\end{array}$ & $\begin{array}{l}\text { Protein } \\
\text { g/l } \\
\text { SMAC }\end{array}$ & $\begin{array}{l}\text { Protein } \\
\text { g/l } \\
\text { NIRS }\end{array}$ \\
\hline 1 & 101 & 173 & 12.8 & 59 & 56 \\
2 & 67 & 150 & 4.9 & 53 & 51 \\
3 & 101 & 140 & 12.9 & 58 & 55 \\
4 & 77 & 63 & 3.6 & 45 & 44 \\
5 & 249 & 13 & 23.5 & 63 & 64 \\
6 & 147 & 17 & 21.9 & 55 & 56 \\
7 & 578 & 5 & 15.9 & 63 & 63 \\
8 & 522 & 7 & 37.3 & 54 & 55 \\
9 & 591 & 6 & 44.7 & 53 & 57 \\
10 & 389 & 10 & 15.3 & 49 & 50 \\
11 & 1035 & 4 & 32.2 & 62 & 63 \\
12 & 1241 & 4 & 20.3 & 58 & 58 \\
13 & 154 & 73 & 22.0 & 64 & 64 \\
14 & 66 & 111 & 4.8 & 50 & 48 \\
15 & 647 & 17 & 35.5 & 47 & 48 \\
16 & 79 & 5 & 5.5 & 99 & 98 \\
\hline
\end{tabular}


High serum concentrations of creatinine or urea did not interfere with near-infrared reflectance spectroscopy measurement of total protein (tab. 2). However, table 2 suggests that near-infrared reflectance spectroscopy analysis of sera with high bilirubin concentrations gives slightly lower values for total protein than measurement by SMAC II. A very turbid, lipaemic serum sample contained $73 \mathrm{~g} / 1$ protein when measured by SMAC II; near-infrared reflectance spectroscopy analysis of this sample gave a result of 72 $\mathrm{g} / \mathrm{l}$ protein.

\section{Discussion}

Near-infrared reflectance spectroscopy is now widely used for the analysis of protein, fat and other components in agricultural products $(4,5)$. Recently, nearinfrared spectrophotometry has also found its first applications in clinical chemistry. Wyatt et al. (8) quantitated changes in the concentrations of oxyhaemoglobin $\left(\mathrm{HbO}_{2}\right)$ and reduced haemoglobin in cerebral blood by near-infrared spectrophotometry: changes in the absorption at three different wavelengths were converted into signals from $\mathrm{HbO}_{2}$ and reduced haemoglobin with use of an algorithm, analogous to that used in the present paper for protein measurement. Koumantakis et al. (6) used the InfraAlyzer for the estimation of fat in faeces. These authors (6) found the analytical precision of the near- infrared reflectance spectroscopy method to be superior to the reference (Van de Kamer method. Our data show high precision for the measurement of total serum protein $(\mathrm{CV}=1.3-3.3 \%)$.

High concentrations of creatinine and urea did not interfere with the near-infrared reflectance spectroscopy measurement of total protein in serum (tab. 2). With four sera with bilirubin concentrations higher than $100 \mu \mathrm{mol} / 1$, the near-infrared reflectance spectroscopy results were $2-3 \mathrm{~g} / 1$ lower than the SMAC II-values. Elevated levels of these three components were also present in some of the sera that were used for calibration; thus an algorithm was generated that converted absorbance data into protein concentrations with no or small interference from these three components.

In summary, this paper shows that the amount of total protein in serum can be accurately estimated by near-infrared reflectance spectroscopy. Although primarily of theoretical interest, this study further extends the application of near-infrared reflectance spectroscopy in clinical chemistry.

\section{Acknowledgement}

We thank Technicon Holland and Bran \& Luebbe Holland for their advice and for allowing us to use the InfraAlyzer 450.

\section{References}

1. Doumas, B. T., Bayse, D., Barnes, K., Carter, R. J., Peters, T. \& Schaffer, R. A. (1981) Clin. Chem. 27, 1642-1650.

2. Ross, D. L. (1985) Proteins. Chapter 9, In: Clinical Chemistry, Principles, Procedures, Correlations (Bishop, M. L., Duben-von Laufen, J. L. \& Fodey, E. P., eds.) pp. 167204. Lippincott J. P. Cy, Philadelphia.

3. Peterson, G. L. (1983) Meth. Enzymology 91, 95-119.

4. Wetzl, D. L. (1983) Anal. Chem. 55, 1165A-1176A.
5. Davies, A. M. C. (1987) Abstract. NIRS-symposium, the Hague, The Netherlands, 16 and 17 april 1987. Technicon, Gorinchem, The Netherlands.

6. Koumantakis, G. \& Radcliff, F. J. (1987) Clin. Chem. 33, 502-506.

7. Instruction for calibration of the InfraAlyzer. Technicon, Gorinchem, The Netherlands.

8. Wyatt, J. S., Cope, M., Delphy, D. T., Wray, S. \& Reynolds, E. O. R. (1986) Lancet $i i, 1063-1066$.

Dr. A. W. van Toorenenbergen Academisch Ziekenhuis Rotterdam-Dijkzigt Centraal Klinisch Chemisch Laboratorium Dr. Molewaterplein 40 NL-3015 GD Rotterdam 
. 